\title{
Psychosine Cytotoxicity in Rat Neural Cell Cultures and Protection by Phorbol Ester and Dimethyl Sulfoxide
}

\author{
SEIICHI SUGAMA, SEUNG U. KIM, HIROYUKI IDA, AND YOSHIKATSU ETO \\ Division of Neurology, Department of Medicine, University of British Columbia, Vancouver, British Columbia, \\ Canada [S.S., S.U.K.J and Department of Pediatrics, Tokyo Jikei University School of Medicine. \\ Tokyo, Japan [S.S., H.I., Y.E.]
}

\begin{abstract}
In Krabbe's disease (globoid cell leukodystrophy), galactosylsphingosine (psychosine) is considered to be a causative agent of the pathology found in the nervous system of the patients. In our study, we examined the cytotoxic effect of psychosine in neural cell cultures derived from the rat nervous system. The concentration of toxic thresholds varied from cell type to cell type. The $\mathbf{5 0 \%}$ of toxic doses for oligodendrocytes, astrocytes, and the sensory neurons of the dorsal root ganglia were 8,20 , and $30 \mu \mathrm{g} / \mathrm{mL}$, respectively. Oligodendrocytes, therefore, appeared to show a higher sensitivity to psychosine than did astrocytes or neurons. When phorbol ester or DMSO was applied simultaneously with psychosine as protective agents in enriched cultures of rat oligodendrocytes, the total number of live cells and galactocerebroside-positive cells and the $2^{\prime} 3^{\prime}$-cyclic nucleotide $3^{\prime}$-phosphohydrolase activity in these cultures were considerably higher as compared with their levels in the experimental cultures treated with psychosine alone. These results indicate that phorbol ester and DMSO could serve as protective agents for psychosine neurotoxicity. (Pediatr Res 28: 473-476, 1990)
\end{abstract}

Abbreviations

GLD, globoid cell leukodystrophy

EMEM, Eagle's minimum essential medium

PDB, 4- $\beta$-phorbol-12, 13-dibutyrate

OL, oligodendrocyte

CNP, 2'3'-cyclic nucleotide $3^{\prime}$-phosphohydrolase

GC, galactocerebroside

GFAP, glial fibrillary acidic protein

NF, neurofilament

$\mathrm{TD}_{50}, \mathbf{5 0} \%$ toxic dose

Krabbe's disease (GLD) is an inherited neurologic disorder in children caused by galactosylceramide- $\beta$-galactosidase deficiency (1). In GLD, unlike in other sphingolipid storage diseases, galactosylceramide, the natural substrate of the deficient enzyme, does not accumulate in the CNS, and the overall concentration in the brain is much lower than normal (2). An abnormal accumulation in the brains of GLD patients of galactosylsphingosine (psychosine), which is also a substrate for the missing enzyme, was demonstrated by Svennerholm et al. (3). These authors confirmed the "psychosine hypothesis" proposed by Miyatake and Suzuki (4) that psychosine is highly cytotoxic and responsible for the extensive pathology of the disease (5).

Received December 18, 1989: accepted June 28, 1990.

Correspondence: Seung U. Kim, M.D., Ph.D., Division of Neurology, University Hospital, University of British Columbia, Vancouver, B.C. V6T IW5. Canada.
Previous studies have reported that psychosine is cytotoxic in the cell culture system (4) and in vivo when it is injected intracerebrally (6). In GLD, the affected organ is almost exclusively the nervous system, which shows dysmyelination of the CNS and the peripheral nerve. To facilitate our understanding of how psychosine elicits dysmyelination of the CNS, we examined its cytotoxic effect on the neural cell cultures derived from newborn rat brain and dorsal root ganglion. In addition, attempts were made to neutralize psychosine cytotoxicity in rat brain cultures by supplementing two reagents, DMSO and phorbol ester PDB, as protective agents. These reagents showed a considerable degree of protective effect on psychosine toxicity in rat neural cell cultures.

\section{MATERIALS AND METHODS}

Cell culture. Dissociated cell cultures of newborn (2-5 d) rat brain were prepared according to the method previously described $(7,8)$. Dispersed cells were plated onto 9-mm Aclar (Allied Chemical Corp., New York, NY) coverslips $\left(5 \times 10^{4}\right.$ cells/coverslip) previously coated with poly-L-lysine $(10 \mu \mathrm{g} / \mathrm{mL})$ that were housed in $35-\mathrm{mm}$ plastic dishes. The nutrient medium was composed of EMEM containing $5 \%$ FCS, $5 \mathrm{mg} / \mathrm{mL}$ Dglucose, and $25 \mu \mathrm{g} / \mathrm{mL}$ gentamicin. Dorsal root ganglia were excised from newborn rats, dissociated into single cells by trypsinization as above, and plated onto the coverslips. The nutrient medium was made of $10 \% \mathrm{FCS}, 100 \mathrm{ng} / \mathrm{mL}$ nerve growth factor, $5 \mathrm{mg} / \mathrm{mL}$ D-glucose, and $25 \mu \mathrm{g} / \mathrm{mL}$ gentamicin in EMEM.

OL of 4-wk-old rats were prepared from the whole brain using the procedure previously described for human OL (9). In brief, the brains were cut into cubes of approximately $3 \times 3 \times 3 \mathrm{~mm}$ and incubated in calcium and magnesium-free Hanks' balanced salt solution containing $0.25 \%$ trypsin and $20 \mu \mathrm{g} / \mathrm{mL}$ DNAse for $45 \mathrm{~min}$ at $37^{\circ} \mathrm{C}$. Dissociated cells were passed through a nylon filter of $100-\mu \mathrm{m}$ pore size, and the filtrate was then centrifuged in $30 \%$ Percoll (Pharmacia, Piscataway, NJ) for $30 \mathrm{~min}$ at 15000 $\mathrm{rpm}$. The OL layer was collected, washed, and resuspended in a nutrient medium of EMEM containing $5 \% \mathrm{FCS}, 5 \mathrm{mg} / \mathrm{mL}$ Dglucose, and $25 \mu \mathrm{g} / \mathrm{mL}$ gentamicin. Collected OL were seeded onto 9-mm Aclar coverslips and in 24 multiwell plates that had been previously coated with poly-L-lysine. All cell cultures were incubated at $37^{\circ} \mathrm{C}$ in a humidified atmosphere of $5 \% \mathrm{CO}_{2}$.

Psychosine, DMSO, and PDB treatment. Psychosine (Sigma Chemical Co., St. Louis, MO) was directly dissolved in the nutrient medium by sonication for $5 \mathrm{~min}$ at the concentration of $0.5 \mathrm{mg} / \mathrm{mL}$ and then sterilized by filtering through a $0.2-\mu \mathrm{m}$ membrane filter. This solution was further diluted to desired concentrations by the nutrient medium. Three to $5 \mathrm{~d}$ after the preparation, cultures were treated with the various concentrations of psychosine.

To determine whether PDB and DMSO protect psychosine 
toxicity, OL cultures were simultaneously incubated with $10 \mu \mathrm{g} /$ $\mathrm{mL}$ psychosine and $10 \mathrm{nM}$ PDB or $0.5 \%$ DMSO. Cell survival, immunohistochemistry, and CNP enzyme assays were performed in these cultures. Preliminary experiments were conducted to ascertain that $10 \mathrm{nM}$ PDB and $0.5 \%$ DMSO at concentration were not toxic to the cultures (data not shown). All determinations were carried out $3 \mathrm{~d}$ after the onset of the treatment.

Determination of cell survival. Three d after the treatment, cell survival was evaluated by the trypan blue exclusion test (10).

Enzyme assay. Activity of CNP was carried out by a modification of the method of Sims and Carnegie (11), with adenosine $2^{\prime}, 3^{\prime}$-cyclic monophosphate as a substrate. Cells grown in 24 multiwell plates were harvested by scraping and then were pelleted by low-speed centrifugation. The pellets were washed twice in PBS and resuspended with $2 \%$ Triton-X imidazole buffer. The spec act of CNP was expressed as nmol substrate converted to product per min of incubation at $37^{\circ} \mathrm{C}$ per well in the homogenate. Protein content was determined by the BioRad assay (BioRad Laboratories, Richmond, CA) using BSA as standard.

Immunohistochemistry. Immunolabeling of cultured cells grown on 9-mm coverslips was performed using mouse anti-GC MAb (a cell type-specific marker for OL) (9), rabbit anti-GFAP antibody (a cell type-specific marker for astrocytes) (12), and rat anti-NF 150-kDa triplet protein MAb (a cell type-specific marker for neurons) (13) as described previously (14). Coverslips were incubated with mouse anti-GC MAb (1:2) for $30 \mathrm{~min}$ at room temperature. This was followed by goat antimouse IgG conjugated to fluorescein (1:40 dilution) for another $30 \mathrm{~min}$. Coverslips were then fixed in cold acid-alcohol $(95 \%$ ethanol, $5 \%$ acetic acid) at $-20^{\circ} \mathrm{C}$ for $15 \mathrm{~min}$. After rehydration with PBS, they were mounted on slides in glycerol-PBS. Cultures were fixed in acid-alcohol as above and then incubated in monoclonal (rat) anti-NF antibody (1:2) or rabbit anti-GFAP antibody (1:50) overnight at $4^{\circ} \mathrm{C}$. Coverslips were washed in PBS and then incubated with fluorescein conjugated with goat antirat or antirabbit IgG (1:40). Immunostained cells were viewed and counted under a Zeiss Universal fluorescence microscope equipped with phase-contrast and fluorescence optics.

Hybridoma cell lines that produce MAb specific for GC (15) and NF (13) were grown in the laboratory (S.U.K.), and culture supernatants were used in immunostaining. Rabbit antibody specific for GFAP was purchased from DAKO (Carpinteria, CA), and fluorescein-conjugated second antibodies were obtained from Cappel (Westchester, PA).

\section{RESULTS}

Psychosine toxicity. Observations of living cells under phase contrast microscopy $3 \mathrm{~d}$ after psychosine treatment showed that the toxic effects of psychosine depended on the concentration of psychosine in the medium. In general, at the lower concentrations, there was an increased perinuclear granularity, formation of intracytoplasmic vacuolation, and inhibited outgrowth of neurites and processes. At the higher concentrations, the cells tended to float off from the coverslips, showing shrinkage of the cell bodies and phase-dark cell bodies indicating cell death.

To determine the effect of the various psychosine concentrations, we used fluorescence microscopic examination to count the total numbers of GC-positive cells (OL), GFAP-positive cells (astrocytes), and NF-positive cells (neurons). Of these, we recorded the number of (and thus the percentage of) OL with normal surface stain, astrocytes with preserved normal configuration and stain, and neurons with processes greater than three cell diameters (Fig. 1). In newborn rat brain cultures, the number of GC-positive OL began to decrease at a psychosine concentration of $2-4 \mu \mathrm{g} / \mathrm{mL}\left(\mathrm{TD}_{50} \sim 8 \mu \mathrm{g} / \mathrm{mL}\right.$ ), whereas the number of GFAP-positive cells (astrocytes) only started to decrease at a psychosine concentration of $8 \mu \mathrm{g} / \mathrm{mL}\left(\mathrm{TD}_{50} \sim 20 \mu \mathrm{g} / \mathrm{mL}\right.$ ); the

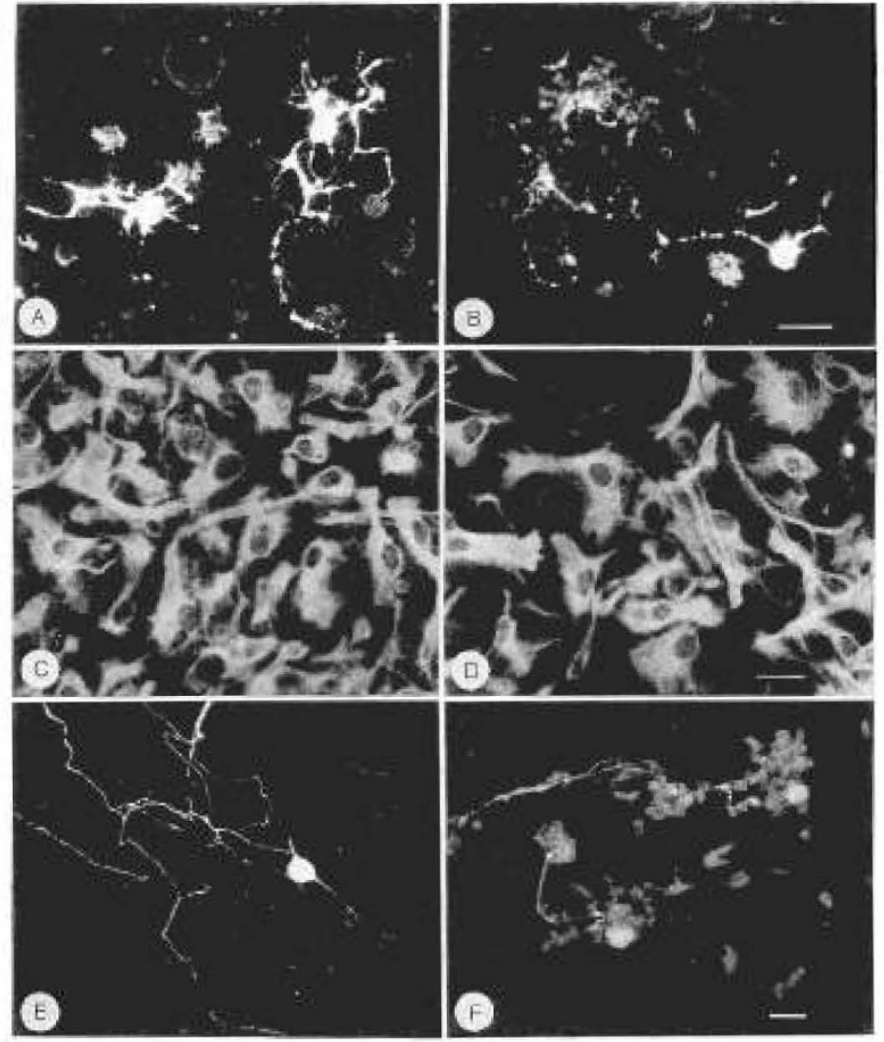

Fig. 1. Cytotoxic effect of psychosine on cultures of newborn rat brain and dorsal root ganglion. $A$ and $B$, OL immunostained for GC ( $A$, control; $B, 8 \mu \mathrm{g} / \mathrm{mL}$ psychosine). $C$ and $D$, astrocytes immunostained for GFAP ( $C$, control; $D, 24 \mu \mathrm{g} / \mathrm{mL}$ psychosine). $E$ and $F$, sensory neuron of dorsal root ganglion immunostained for NF ( $E$, control; $F, 30$ $\mu \mathrm{g} / \mathrm{mL}$ psychosine). Bars indicate $20 \mu \mathrm{m}$.

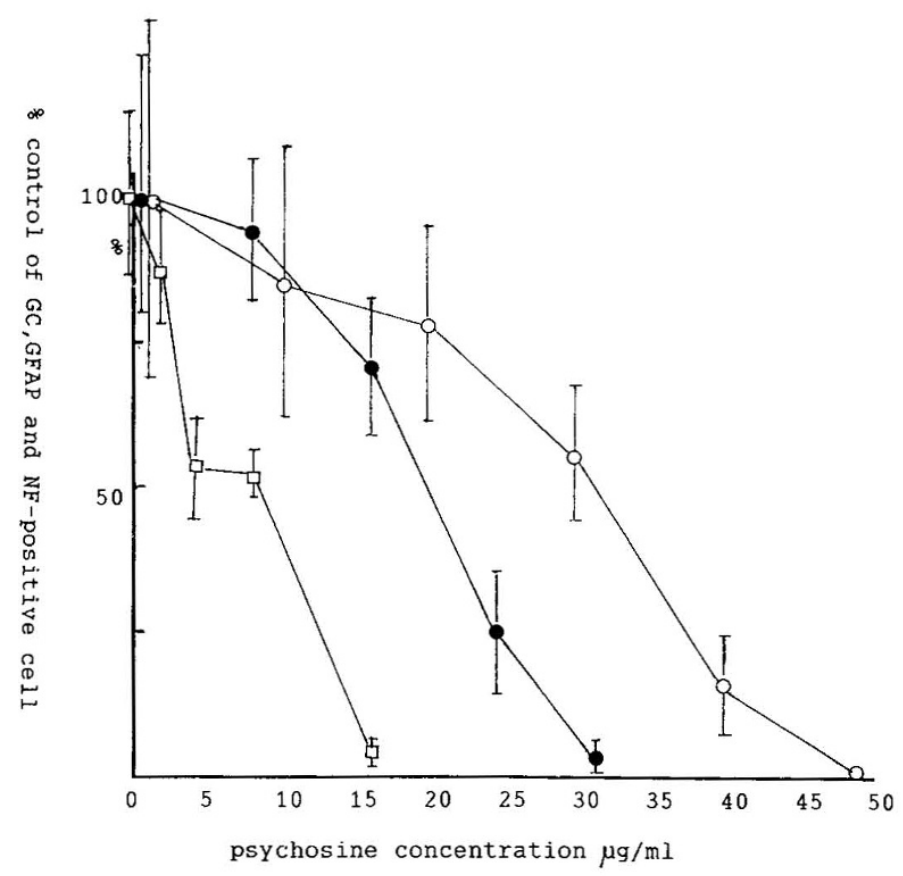

Fig. 2. Percent of GC-positive (OL), GFAP-positive (astrocytes), and NF-positive (neurons) cells in newborn rat brain and dorsal root ganglion cultures exposed to various concentrations of psychosine as compared with the control (100\%). GC-positive cells, $\square$; GFAP-positive cells, $\mathbf{0}$; and NF-positive cells, $\bigcirc$. Criteria of the recorded cells are described in Results. 


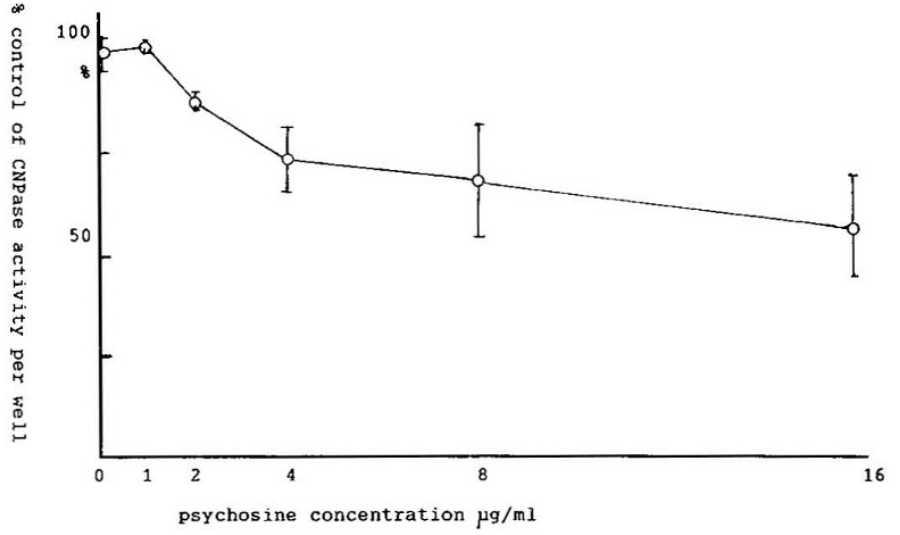

Fig. 3. Percent of CNP activity in newborn rat brain cultures exposed to various concentrations of psychosine as compared with the control $(100 \%)$.
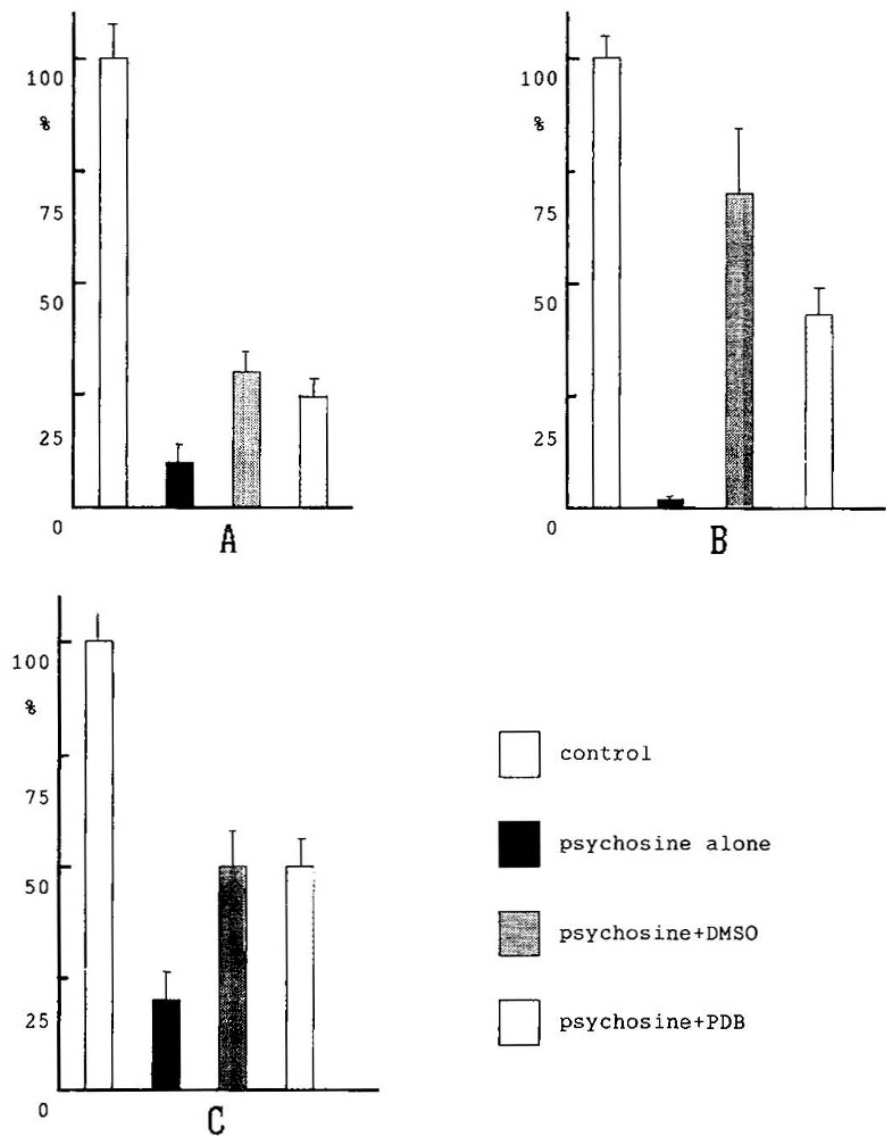

Fig. 4. Protective effects of PDB and DMSO over psychosine toxicity on newborn rat brain cultures. Cultures were simultaneously incubated with $10 \mu \mathrm{g} / \mathrm{mL}$ psychosine plus $10 \mathrm{nM}$ PDB or $0.5 \%$ DMSO. $A$, number of live cells per well; $B$, number of GC-positive OL per four coverslips; $C, \mathrm{CNP}$ activity per well

number of NF-positive neurons began to decrease at a psychosine concentration of $10 \mu \mathrm{g} / \mathrm{mL}\left(\mathrm{TD}_{50} \sim 30 \mu \mathrm{g} / \mathrm{mL}\right.$ ) (Fig. 2).

Sister cultures of rat brain were treated with the various concentrations of psychosine, and the activity of CNP was measured. As shown in Figure 3, CNP activity started to decrease at the concentration of $2 \mu \mathrm{g} / \mathrm{mL}$ psychosine. When GC-positive cells were examined under the fluorescence microscope (Fig. 2), the number of OL dropped to $50 \%$ at a psychosine concentration of $4 \mu \mathrm{g} / \mathrm{mL}$ and to nearly zero at a psychosine concentration of $16 \mu \mathrm{g} / \mathrm{mL}$. Although GC immunoreactive cells dropped to the $50 \%$ level, the CNP activity (Fig. 3) decreased only $25 \%$ at $4 \mu \mathrm{g} /$

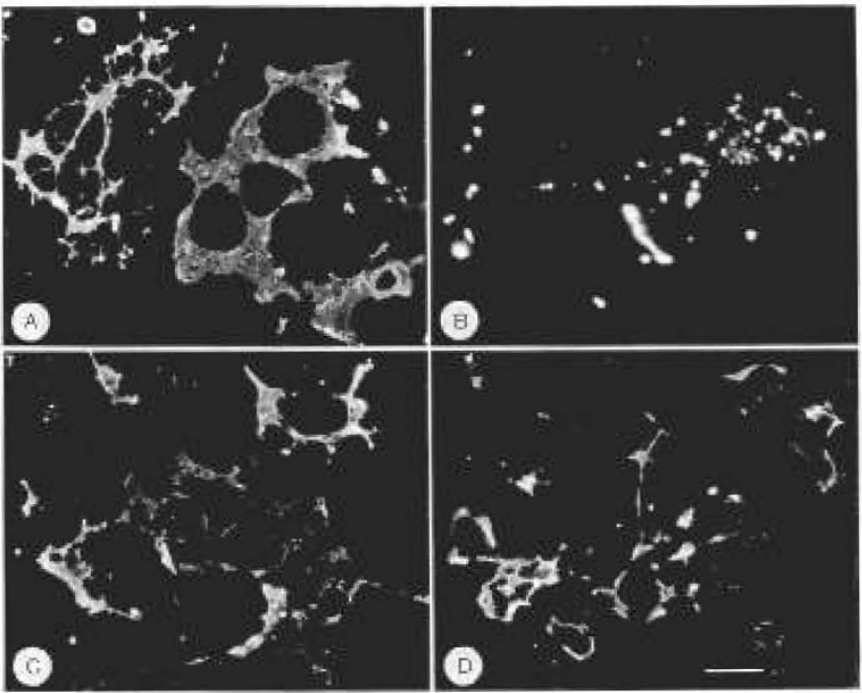

Fig. 5. Protective effects of PDB and DMSO over psychosine toxicity. Immunofluorescence labeling of rat OL cultures by anti-GC antibody. $A$, control; $B, 10 \mu \mathrm{g} / \mathrm{mL}$ psychosine alone for $3 \mathrm{~d} ; C$, psychosine +10 $\mathrm{nM}$ PDB; $D$, psychosine + 0.5\% DMSO. Bar indicates $20 \mu \mathrm{m}$.

$\mathrm{mL}$ psychosine, and the CNP activity was $50 \%$ of the control when GC-positive cells were nearly zero at a psychosine concentration of $16 \mu \mathrm{g} / \mathrm{mL}$. This discrepancy might be explained by the loss of GC immunostaining on the OL cell surface while retaining enzyme activity of CNP after the exposure to psychosine.

Protective effects of PDB and DMSO. Because OL had the greater sensitivity to psychosine, we focussed on the effects of protective reagents on OL. Using the Percoll density gradient method described above, we obtained OL-rich cultures with 80 $95 \%$ purity as determined by immunostaining with mouse anti$\mathrm{GC} \mathrm{MAb}$

In rat OL cultures treated with psychosine alone for $3 \mathrm{~d}$, there were few live cells under the phase contrast microscopy and GCpositive cells after the immunostaining. When the cultures were supplemented with PDB or DMSO, there were a considerable number of well-preserved live cells and also normal-appearing GC-immunoreactive OL (Figs. $4 A$ and $B$ and 5). The CNP activity in the cultures exposed to psychosine supplemented with PDB or DMSO was approximately $50 \%$ of the normal controls, but this activity was more than 2 -fold that of the cultures exposed to psychosine alone (approximately $20 \%$ of the normal control) (Fig. 5).

\section{DISCUSSION}

The cytotoxicity of psychosine is now well known, and the extensive pathology found in Krabbe's disease could be attributed to the toxic effects of accumulated psychosine in the affected tissues. When psychosine was injected into rat brain, necrosis and hemorrhage occurred and the white matter of the animals was found to be edematous with numerous degenerating myelin and axons (6). When more than $0.1 \mathrm{mM}$ of psychosine was applied to cultured rat cerebellar explants, whole explants degenerated completely (4). In tissue, only OL synthesized any substantial amount of cerebroside and psychosine. Thus, the deficiency in $\beta$-galactosidase enzyme in GLD and twitcher mutant, leading to accumulation of psychosine, would only be apparent in OL and would show little toxic activity toward non-OL such as astrocytes or neurons. In our study, psychosine was found to be more toxic to OL than to astrocytes or neurons as demonstrated. Nevertheless, psychosine cytotoxicity was also evident in astrocytes and neurons.

As shown in Figure 2, the number of GC-positive OL drops to $50 \%$ at a psychosine concentration of $4 \mu \mathrm{g} / \mathrm{mL}$ and to nearly zero at $16 \mu \mathrm{g} / \mathrm{mL}$. When CNP activity was assayed (Fig. 3), the 
activity dropped to $25 \%$ at $4 \mu \mathrm{g} / \mathrm{mL}$ and to $50 \%$ at $16 \mu \mathrm{g} / \mathrm{mL}$. This discrepancy in the results may come from the difference in the sensitivity of detection systems used. Fluorescence microscopy of GC immunostaining of cultured OL involves incubation of live cells in antibody solutions for about $1 \mathrm{~h}$. During this procedure, damaged cells are prone to detach from the coverslips, resulting in lower numbers than expected. For this reason, data obtained by CNP biochemical assay are often more reliable than results of immunostaining.

The severity of psychosine toxicity was dose dependent, but the $\mathrm{TD}_{50}$ of psychosine varied from one cell type to another. The question is where these differences come from. In a previous study of twitcher mouse (16), the concentration of psychosine was found to be several times higher in the nervous tissue (cerebrum, $63 \mathrm{ng} / \mathrm{mg}$ protein; spinal cord, $312 \mathrm{ng} / \mathrm{mg}$ protein) than in the somatic organs (liver, $0.4 \mathrm{ng} / \mathrm{mg}$ protein; kidney, 10 $\mathrm{ng} / \mathrm{mg}$ protein). The concentration of psychosine in somatic organs and the brain of infantile GLD (17) and twitcher mouse (16) correlates well with pathologic changes. Because psychosine is a lysosphingolipid of GC, these two are chemically very close. Therefore, psychosine might accumulate in the myelin sheath in place of GC, a major component of myelin, and lead to the demise of OL, the cells that are responsible for synthesis and maintenance of central myelin. The reason these cell types are not involved in the pathogenesis of GLD and the twitcher mutant mouse might be that neurons and astrocytes do not contain any noticeable amount of GC or psychosine. Although the mechanism of psychosine toxicity has not been clarified, recent studies have shown several interesting findings concerning psychosine biochemistry. Psychosine has been demonstrated to inhibit phosphorylation (18), cytochrome oxidase C (19), and protein kinase $\mathrm{C}$ activity (20). All these inhibitory activities of psychosine may also contribute to the neurotoxic effects attributed to psychosine in tissues.

The protective effects of phorbol ester and DMSO on psychosine toxicity were examined in culture models, and the results indicate that phorbol ester and DMSO were effective in attenuating psychosine neurotoxicity. Phorbol ester has a variety of effects on the nervous system. The effects of phorbol ester are mediated by a specific cell membrane receptor, which is now known to be the enzyme protein kinase $C$, that is particularly abundant in the nervous system (21-23). Psychosine inhibits protein kinase $\mathrm{C}$ activity, and at a higher concentration it becomes cytotoxic (20). We expected that phorbol ester would negate the inhibition of protein kinase $\mathrm{C}$ by psychosine because phorbol ester is one of the most effective protein kinase $\mathrm{C}$ activators. We therefore attempted to apply phorbol ester as a protective agent for psychosine toxicity. Another reagent, DMSO, also is known to possess many stimulatory functions for a variety of cells (24). A recent study has shown that activities of several lysosomal enzymes, including $\beta$-galactosidase, were stimulated in DMSO-treated fibroblast cultures (25). We predicted that applying DMSO together with psychosine would enhance the degradation of psychosine and thus result in reduction in psychosine toxicity. Both of the reagents, phorbol ester and DMSO, apparently protected cultured OL to a certain degree from psychosine toxicity.

Recently, a number of procedures for the treatment of lysosomal storage diseases, such as enzyme replacement therapy (bone marrow transplantation, lysosomal therapy, and gene transfer), have been explored, but none of these have been successful in preventing or treating brain damage. Because DMSO has been used in a variety of clinical settings (24), effectiveness of this reagent and also others such as phorbol esters or protein kinase $\mathrm{C}$ activators might form the first step for a chemotherapeutic approach for GLD patients.

\section{REFERENCES}

1. Suzuki K, Suzuki Y 1970 Globoid cell leukodystrophy (Krabbe's disease): deficiency of galactocerebroside $\beta$-galactosidase. Proc Natl Acad Sci USA 66:302-309

2. Suzuki K, Suzuki Y 1983 Galactosylceramide lipidosis: globoid cell leukodystrophy (Krabbe's disease). In: Stanbury JB, Wyngaarden JB, Fredrickson DS, Goldstein JL, Brown MS (eds) The Metabolic Basis of Inherited Disease. McGraw-Hill, New York, pp 857-880

3. Svennerholm L, Vanier M-T, Mansson J-E 1980 Krabbe's disease: a galactosylsphingosine (psychosine) lipidosis. J Lipid Res 21:53-64

4. Miyatake T, Suzuki K 1972 Globoid cell leucodystrophy: additional deficiency of psychosine galactosidase. Biochem Biophys Res Commun 48:538-543

5. Taketomi T, Yamakawa $\Upsilon 1964$ Physiological activity of psychosine. Jpn J Exp Med 34:255-265

6. Suzuki K, Tanaka H, Suzuki K 1976 Studies on the pathogenesis of Krabbe's leucodystrophy: cellular reaction of the brain to exogenous galactosylsphingosine, monogalactosyl diglyceride and lactosylceramide. In: Volk BW, Schneck L (eds) Current Trends in Sphingolipidoses and Allied Disorders. Plenum Press, New York, pp 99-114

7. Kim SU, Stern J, Kim MW, Pleasure DE 1983 Culture of purified rat astrocytes in serum-free medium supplemented with mitogen. Brain Res 274:79-86

8. Kim SU 1985 Antigen expression by glial cells grown in culture. $J$ Neuroimmunol 8:255-282

9. Kim SU, Sato Y, Silberberg DH, Pleasure DE, Rourke LB 1983 Long-term culture of human oligodendrocytes. J Neurol Sci 62:295-301

10. Freshney R 1983 Culture of Animal Cells. Alan R Liss, New York

11. Sims NR, Carnegie PR 1976 A rapid assay for $2^{\prime}, 3^{\prime}$-cyclic nucleotide $3^{\prime}$ phosphohydrolase. J Neurochem 27:769-772

12. Eng EF, Bigbee JW 1978 Immunohistochemistry of nervous system specific antigens. In: Agranoff BW, Aprison MH (eds) Advances in Neurochemistry, Vol 3. Plenum Press, New York, pp 43-98

13. Lee V, Wu L, Schlaepfer WW 1982 Monoclonal antibodies recognize individual neurofilament triplet proteins. Proc Natl Acad Sci USA 79:6089-6092

14. Raff M, Field K, Hakomori S, Mirsky R, Pruss R, Winter J 1979 Cell-type specific markers for distinguishing and studying neurons and the major class of glial cells in culture. Brain Res 174:283-308

15. Ranscht B, Clapshaw P, Price J, Noble M, Seifert W 1982 Development of oligodendrocytes and Schwann cells studies with a monoclonal antibody against galactocerebroside. Proc Natl Acad Sci USA 74:2709-2713

16. Kobayashi T, Shimada H, Goto I, Yamanaka T, Suzuki Y 1987 Globoid cell leukodystrophy is a generalized galactosylsphingosine (psychosine) storage disease. Biochem Biophys Res Commun 144:41-46

17. Kobayashi T, Goto I, Yamanaka T, Suzuki Y, Nakano T, Suzuki K 1988 Infantile and fetal globoid cell leukodystrophy: analysis of galactosylceramide and galactosylsphingosine. Ann Neurol 24:517-522

18. Strasberg P 1986 Cerebrosides and psychosine disrupt mitochondrial functions. Biochem Cell Biol 64:485-489

19. Igisu H, Nakamura M 1986 Inhibition of cytochrome $C$ oxidase by psychosine (galactosylsphingosine). Biochem Biophys Res Commun 137:323-327

20. Hannun YA, Bell RM 1989 Functions of sphingolipids and sphingolipid breakdown products in cellular regulation. Science 243:500-507

21. Blumberg PM, Driedger PE, Rossow PW 1976 Effect of a phorbol ester on a transformation-sensitive surface protein of chick fibroblasts. Nature 264:446-447

22. Yong VW, Sekiguchi S, Kim MW, Kim SU 1988 Phorbol ester enhances morphological differentiation of oligodendrocytes in culture. J Neurosci Res 19:187-194

23. Nishizuka Y 1986 Studies and perspectives of protein kinase C. Science 223:305-311

24. Jacob SW, Herschler R 1983 Introductory remarks: dimethyl sulfoxide after twenty years. Ann NY Acad Sci 411:13-17

25. Sakuragawa N, Sato M, Yoshida Y, Kamo I, Arima M, Satoyoshi E 1985 Effects of dimethylsulfoxide on sphingomyelinase in cultured human fibroblasts and correction of sphingomyelinase deficiency in fibroblasts from Niemann-Pick patients. Biochem Biophys Res Commun 126:756-762 